\title{
Hubungan Antara Pengetahuan Ibu dan IMD Dengan Praktik ASI Eksklusif
}

\section{The Relationship Between Mother's Knowledge and Early Breastfeeding Initiation With Exclusive Breast-Feeding Practices}

\author{
Zuhud Nur Rosyid ${ }^{* 1}$, Sri Sumarmi ${ }^{1}$
}

\begin{abstract}
ABSTRAK
Latar belakang : Air Susu Ibu (ASI) merupakan makanan yang paling tepat diberikan pada bayi. Air susu ibu satu-satunya minuman atau makanan yang diperlukan bayi pada usia 0-6 bulan pertama. ASI membantu pertumbuhan dan perkembangan, mengandung anti bodi dan zat gizi penting lainnya yang mampu melindungi bayi dari berbagai penyakit. Pada tahun 2013, cakupan ASI eksklusif di Puskesmas Ayah I sebesar 87, 65\%, terjadi penurunan pada tahun 2014 dan tahun 2015 menjadi $78,26 \%$ dan $71,65 \%$. Terdapat beberapa faktor yang berhubungan dengan perilaku pemberian ASI secara Eksklusif.

Tujuan: Tujuan dari penelitian ini yaitu menganalisis hubungan antara pengetahuan ibu dan IMD dengan pemberian ASI secara eksklusif pada wilayah kerja Puskesmas Ayah I Kebumen.

Metode : penelitian ini bersifat kuantitatif dengan desain cross sectional. Penelitian dilakukan bulan Juni sampai Agutus tahun 2017. Populasi dalam penelitian ini yaitu seluruh ibu yang pernah atau sedang menyusui dan memiliki bayi usia 6-11 bulan di desa Tlagasari, Ayah, dan Bulurejo Puskesmas Ayah I. Sampel diambil melalui metode proportional random sampling dan diperoleh sampel sebesar 61 responden. Analisis data menggunakan uji chi-square.

Hasil : Bahwa ada hubungan yang bermakna antara pengetahuan ibu dengan pemberian ASI secara eksklusif $(p=0,000)$, dan IMD dengan pemberian ASI secara eksklusif $(p=0,025)$.

Kesimpulan : Tingkat pengetahuan ibu mengenai ASI eksklusif berpengaruh terhadap keberhasilan praktik pemberian ASI eksklusif. Adanya praktik IMD oleh ibu, berpeluang lebih besar dalam memberikan ASI eksklusif pada bayi.
\end{abstract}

Kata kunci : pengetahuan ibu, IMD dan ASI eksklusif 


\section{ABSTRACT}

Background: Breast milk is the most appropriate food given to babies. Breast milk is the only drink or food that a baby needs at the age of 0-6 months first. Breast milk helps growth and development, contains anti-body and other essential nutrients that can protect babies from various diseases. In 2013, the exclusive breast milk presentation at Puskesmas Ayah I is 87.65\%, decreasing in 2014 and 2015 become $78.26 \%$ and $71.65 \%$. Many factors can influence the behavior of exclusive breastfeeding.

Objectives: The purpose of this research was to analyze the relationship between mother knowledge and early breastfeeding initiation practice with exclusive breastfeeding prectices in the working area of Puskesmas Ayah I Kebumen Ditrict.

Methods: The type of this research was quantitative using cross sectional design. This study was conducted from June-August of 2017. The population used was all mothers who were breastfeeding and had infants aged 6-11 months in three villages in the working area of Puskesmas Ayah I namely Tlagasari, Ayah and Bulurejo villages. Sampling by proportional random sampling method with sample size were 61 respondents. Data was analised by chi-square test.

Results: The result showed that there was a relationship between mothers's knowledge and exclusive breastfeding practice $(p=0.000)$, and early breastfeeding initiation practice with Exclusive Breastfeeding practice $(p=0.025)$

Conclusion: The mother's knowledge level on exclusive breastfeeding affects the success of exclusive breastfeeding practices. The existence of early initiation of breastfeeding practices by the mother, a greater chance in giving exclusive breastfeeding in infants.

Keywords: exclusive breastfeeding, Mother Knowledge, Early Breastfeeding Initiation

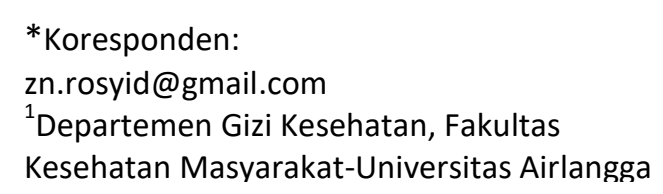

\section{PENDAHULUAN}

Sumber Daya Manusia (SDM) yang berkualitas adalah aset dalam pembangunan bangsa. SDM yang berkualitas dapat diupayakan sejak dini salah satunya dengan pemberian ASI eksklusif. ASI eksklusif yaitu pemberian ASI saja dari bayi lahir sampai dengan usia enam bulan. Pemberian ASI eksklusif sejak dini bermanfaat untuk meningkatkan kekebalan tubuh bayi. World Health Organization (WHO) merekomendasikan pemberian ASI eksklusif 6 bulan $^{1}$. Di Indonesia, hak anak untuk mendapatkan ASI diatur dalam Peraturan Pemerintah (PP) Nomor 33 Tahun 2012 tentang pemberian ASI eksklusif. Dalam PP tersebut, pasal 6 berbunyi "Setiap Ibu yang melahirkan harus memberikan ASI eksklusif kepada bayi yang dilahirkannya" ${ }^{2}$.

Data SDKI 2012 menunjukkan persentase bayi menerima ASI eksklusif di Indonesia yaitu $42 \%^{3}$ dan menurun menjadi $30,2 \%{ }^{4}$ pada tahun 2013. Dari tahun 2013 sampai dengan 2015 presentasi pemberian ASI Eksklusif 0-6 bulan di Jawa Tengah mengalami trend naik yaitu $52,99 \%(2013)^{5}$, $60,7 \%(2014)^{6}$ dan $61,6 \%(2015)^{7}$. Persentase pemberian ASI eksklusif 0-6 bulan di Kabupaten Kebumen selama tiga tahun terakhir mengalami fluktuasi. Pada tahun 2013 cakupan ASI eksklusif $61,17 \%^{8}$, tahun 2014 turun menjadi 59,3\% ${ }^{9}$, tahun 2015 naik menjadi $68,3 \%{ }^{10}$ dan angka menunjukkan bahwa cakupan ASI eksklusif di kabupaten Kebumen masih di bawah target nasional 80 ${ }^{11}$. 
Untuk mendapatkan kelancaran proses pemberian ASI Eksklusif salah satu penentu kesuksesannya adalah dengan melakukan Inisiasi Menyusu Dini (IMD) ${ }^{12}$. IMD yaitu proses menyusu yang dimulai secepatnya segera setelah bayi lahir dengan cara melakukan kontak kulit antara bayi dengan ibu. Proses ini dilakukan minimal satu jam atau proses menyusu pertama selesai (jika menyusu pertama lebih dari satu jam) ${ }^{13}$. Menurut Fikawati dan Syafiq (2009) ibu yang melakukan IMD mempunyai kemungkinan 5-8 kali lebih besar untuk memberikan ASI eksklusif $^{14}$. Hasanah dan Nindya (2015) juga menyebutkan bahwa ibu yang melakukan IMD dan dan memberikan ASI ekskusif sebanyak $88,9 \%$ sedangkan ibu tidak IMD dan tidak memberikan ASI eksklusif sebanyak $98 \%{ }^{15}$. Cakupan IMD tingkat nasional mengalami kenaikan dari $29,3 \%(2010)^{16}$ menjadi $34,5 \%$ $(2013)^{4}$.

Salah satu penyebab kegagalan ASI ekskusif yaitu pemberian makanan prelakteal ${ }^{17}$. Data Riskesdas 2013 menunjukkan cakupan makanan prelakteal yang diberikan pada bayi di Indonesia sebesar 44,3\%. Makanan prelakteal tertinggi berupa susu formula $(79,8 \%)$, madu $(14,3 \%)$, dan air putih $(13,2 \%)^{4}$. Bentuk makanan prelakteal diberikan dalam bentuk lembik dan cair $(60,3 \%)^{2}$.

Praktik pemberian makanan prelakteal dipengaruhi banyak faktor diantaranya tingkat pengetahuan ibu, dan praktik IMD. Pengetahuan merupakan domain yang penting dalam menentukan tindakan seseorang ${ }^{18}$. Menurut Legesse (2014), bayi diberikan makanan prelakteal 3,7 kali lebih besar oleh ibu yang tidak mengetahui risiko pemberian makanan prelakteal ${ }^{19}$. Penelitian lainnya menyebutkan bahwa ibu dengan pengetahuan kurang baik berkecenderungan 3,405 kali untuk memberikan makanan prelakteal pada bayinya ${ }^{20}$.

Di Puskesmas Ayah I Kabupaten Kebumen persentase ASI eksklusif 0-6 bulan masih rendah dan cenderung trennya menurun yaitu $87,65 \%(2013)^{21}, 78,26 \%$ $(2014)^{22}$ dan $71,65 \% \quad(2015)^{23}$. Terdapat banyak faktor penyebab rendahnya ASI Eksklusif di antaranya tingkat pengetahuan ibu dan praktik IMD. Fikawati \& Syafiq (2009) menyebutkan bahwa lima dari tujuh informan ASI Eksklusif mempunyai pengetahuan yang baik. Informan tahu dengan tepat tentang pemberian ASI secara eksklusif diberikan dalam kurun waktu enam bulan dan tidak diberikan makanan atau minuman lainnya ${ }^{14}$. Menurut Rohmin dkk (2015) ibu yang tidak melakukan IMD mempunyai kecenderungan 18,983 kali untuk memberikan makanan prelakteal pada bayinya. Namun pemberian makanan prelakteal menjadi salah satu penyebab gagalnya pemberian ASI Eksklusif ${ }^{20}$. Rendahnya cakuan ASI eksklusif dan belum tersedianya data pemberian makanan prelakteal pada bayi di wilayah Puskesmas Ayah I menjadi alasan peneliti melakukan penelitian di daerah tersebut.

\section{METODE}

Penelitian dengan rancangan cross sectional dilaksanakan di tiga desa (Tlagasari, Ayah, Bulurejo) Puskesmas Ayah I Kebumen, dengan waktu pengambilan data yaitu pada bulan Juni - Agustus 2017. Alasan dipilih 3 desa tersebut karena wilayah Puskesmas Ayah I terdiri dari pegunungan, pantai dan dataran rendah sehingga peneliti mengambil 3 desa yaitu Tlagasari mewakili daerah pegunungan, Ayah mewakili pantai dan Bulurejo mewakili dataran rendah. Populasi dalam penelitian ini sebesar 72 ibu dan Besar sampel 61 ibu bayi usia 6-11 bulan dengan kriteria inklusi yaitu ibu yang pernah atau sedang menyusui dan tinggal di wilayah kerja Puskesmas Ayah I. Sampel diambil dengan metode proportional random sampling.

Variabel yang diteliti meliputi pengetahuan ibu dan praktik IMD (variabel bebas) dan pemberian ASI secara eksklusif (variabel tergantung). Wawancara menggunakan kuesioner. Untuk pengetahuan dikategorikan menjadi 3 yaitu Kurang (Jawaban benar < 56 \%), Cukup (jawaban benar 56-75\%), Baik (jawaban benar 76-100 $\%)^{24}$. Untuk masing-masing kategori IMD dan ASI Eksklusif dikategorikan menjadi Ya dan Tidak, disimpulkan dari beberapa pertanyaan yang terdapat pada kuesioner.

Uji Chi-square digunakan untuk menganalisis hubungan antar variabel. Penelitian ini telah mendapatkan sertifikat laik 
etik dari komite etik penelitian kesehatan Fakultas Kesehatan Masyarakat Universitas Airlangga dengan nomor 246-KEPK.

\section{HASIL DAN PEMBAHASAN}

\section{Karakteristik responden penelitian}

Karakteristik responden meliputi usia/umur, Tingkat pendidikan formal, pekerjaan, tingkat pengetahuan ibu, praktik IMD, Praktik ASI Eksklusif. Berdasarkan Tabel 1 dapat dilihat bahwa usia ibu paling banyak termasuk golongan umur 20-35 tahun. Umur 20-35 tahun merupakan kelompok umur yang paling baik untuk hamil dan menyusui $\mathrm{Hal}$ ini disebabkan secara fisik sudah cukup kuat dan secara mental juga sudah dewasa. Produksi ASI pada umur lebih dari 35 tahun juga mulai menurun bila dibandingkan dengan ibu dengan umur 20-35 tahun ${ }^{25}$. Menurut Arini (2012), risiko yang muncul jika ibu melakukan persalinan pada usia $>35$ tahun yaitu terjadi anemia gizi yang dapat mempengaruhi produksi $\mathrm{ASI}^{26}$. Meskipun $82 \%$ ibu termasuk dalam golongn umur 20-35 tahun, akan tetapi cakupan pemberian ASI eksklusif di Puskesmas Ayah I masih rendah yaitu $55,7 \%$ yang berarti belum mencapai target nasional.

Masih terdapat responden yang tidak tamat SD (1,6\%) dan tamat SD/Sederajat $(9,8 \%)$. Rendahnya tingkat pendidikan akan berpengaruh pada ibu dalam menghadapi masalah pemberian ASI. Pengetahuan gizi ibu juga dipengaruhi oleh pendidikan formal. Ibu dengan pendidikan lebih tinggi pada umumnya lebih terbuka dalam menerima perubahan dalam berperilaku untuk memelihara kesehatan sehingga dapat mengubah perilaku kesehatan untuk lebih peduli terhadap gizi anak dan keluarga salah satunya dengan memberikan ASI eksklusif pada bayinya ${ }^{27}$.

Tabel 1. Distribusi tentang karakteristik responden

\begin{tabular}{lcc}
\hline \multicolumn{1}{c}{ Karakteristik } & \multicolumn{2}{c}{ Jumlah responden penelitian } \\
\cline { 2 - 3 } & $\mathbf{n}=61$ & $\%$ \\
\hline Umur Ibu & 50 & 82 \\
20-35 tahun & 11 & 18 \\
<20 tahun atau > 35 tahun & & \\
Tingkat pendidikan & 1 & 1,6 \\
$\quad$ Tidak sekolah/tidak tamat SD & 6 & 9,8 \\
$\quad$ Lulus SD/Sederajat & 30 & 49,2 \\
Lulus SMP/Sederajat & 22 & 36,1 \\
Lulus SMA/Sederajat & 2 & 3,3 \\
Lulus Diploma/Sarjana & & 1,6 \\
Pekerjaan & 1 & 3,3 \\
PNS & 2 & 11,5 \\
Pegawai Swasta & 7 & 1,6 \\
Wiraswasta & 1 & 77,0 \\
Buruh & 47 & 4,9 \\
Tidak bekerja / IRT & 3 & 19,7 \\
Lainnya & & 39,3 \\
Tingkat Pengetahuan & 12 & 41,0 \\
Kurang & 24 & 52,7 \\
Cukup & 25 & 47,5 \\
Baik & & 44,3 \\
Inisiasi Menyusu Dini (IMD) & 32 & 55,7 \\
Tidak melakukan IMD & 29 & \\
Melakukan IMD & & \\
Pemberian ASI Eksklusif & 27 & \\
Non ASI Eksklusif & 34 & \\
ASI Eksklusif & & \\
\hline
\end{tabular}


Wilayah kerja Puskesmas Ayah I termasuk wilayah pedesaan. Sebanyak $77,0 \%$ responden merupakan ibu rumah tangga, artinya banyak responden yang mempunyai banyak kesempatan mengasuh anak. Berbeda dengan responden yang bekerja, anak dititipkan kepada orang tua dan diasuh oleh orang tua responden. Hal ini menyebabkan waktu ibu dalam mengurus anak menjadi berkurang dan berakibat ada kecenderungan ibu untuk memberikan susu formula. Keadaan ini menyebabkan frekuensi penyusuan menjadi berkurang dan berakibat pada menurunnya produksi ASI. Bekerja sambil tetap memberi ASI merupakan suatu tantangan karena menyusui memerlukan proses adaptasi antara ibu dan anak. Ibu harus berjuang di tempat kerja untuk memerah ASI dan juga dituntut untuk tetap bisa bekerja dengan baik ${ }^{28}$.

Dalam penelitian ini, tingkat pengetahuan diukur menggunakan kuesioner yang terdiri dari 10 pertanyaan yaitu tentang definisi ASI Eksklusif, manfaat Kolostrum, umur bayi seharusnya diberikan ASI Eksklusif, manfaat ASI, makanan prelakteal, daya tahan terhadap bayi yang baru saja lahir tanpa makanan atau minuman selama $2 \times 24$ jam, perbandingan antara susu formula dengan ASI, daya simpan ASI perah, cara mengatasi kurang ASI, Hal yang dilakukan jika ibu menyusui sedang sakit. Distribusi responden menjawab dengan benar disajikan pada Tabel 2.

Tabel 2. Distribusi responden menjawab dengan benar

\begin{tabular}{lcc}
\hline \multirow{2}{*}{ Komponen pertanyaan } & \multicolumn{2}{c}{$\begin{array}{c}\text { Jumlah Responden yang menjawab } \\
\text { dengan benar }\end{array}$} \\
\cline { 2 - 3 } & $\mathbf{n}$ & \% \\
\hline Definisi ASI eksklusif & 48 & 78,7 \\
Manfaat Kolostrum & 51 & 83,6 \\
Umur bayi seharusnya diberikan ASI Eksklusif & 47 & 77,0 \\
Manfaat ASI & 61 & 100,0 \\
Makanan prelakteal & 31 & 50,88 \\
Daya tahan bayi baru lahir tanpa makanan atau & 25 & 41,0 \\
minuman & 57 & 93,4 \\
Perbandingan ASI dengan susu formula & 49 & 80,3 \\
Daya simpan ASI perah & 52 & 85,2 \\
Cara mengatasi kurang ASI & 26 & 42,6 \\
Hal yang dilakukan jika ibu menyusui sedang sakit & & \\
\hline
\end{tabular}

Tabel 3. Distribusi pola pemberian ASI, pemberian makanan prelakteal dan jenis makanan prelakteal

\begin{tabular}{lcc}
\hline \multicolumn{1}{c}{ Variabel } & \multicolumn{2}{c}{ Jumlah Responden } \\
\cline { 2 - 3 } & $\mathbf{n}$ & $\%$ \\
\hline Pola pemberian ASI & 22 & 36,1 \\
$\quad$ Menyusui Parsial & 5 & 8,2 \\
Menyusui Predominan & 34 & 55,7 \\
$\quad$ Menyusui Eksklusif & & \\
Pemberian Makanan Prelakteal & 13 & 48,1 \\
$\quad$ Memberikan makanan Prelakteal & 14 & 51,9 \\
$\quad$ Tidak memberikan makanan Prelakteal & & 84,6 \\
Jenis Makanan Prelakteal & 11 & 7,7 \\
Susu Formula & 1 & 7,7 \\
Madu & 1 & \\
Air putih &
\end{tabular}


Tabel 4. Distribusi responden berdasarkan tingkat pengetahuan ibu dan ASI eksklusif.

\begin{tabular}{|c|c|c|c|c|c|c|c|}
\hline \multirow{3}{*}{ Tingkat pengetahuan ibu } & \multicolumn{6}{|c|}{ Praktik Pemberian ASI } & \multirow{3}{*}{$\begin{array}{c}\text { Hasil uji chi- } \\
\text { square } \\
\text { (P value) }\end{array}$} \\
\hline & \multicolumn{2}{|c|}{ Tidak } & \multicolumn{2}{|c|}{$\mathrm{Ya}$} & \multicolumn{2}{|c|}{ Total } & \\
\hline & $\mathrm{n}$ & $\%$ & $\mathbf{n}$ & $\%$ & $\mathbf{N}$ & $\%$ & \\
\hline Kurang & 8 & 66,7 & 4 & 33,3 & 12 & 100 & \\
\hline Cukup & 17 & 70,8 & 7 & 29,2 & 24 & 100 & 0,000 \\
\hline Baik & 2 & 8,0 & 23 & 92,0 & 25 & 100 & \\
\hline
\end{tabular}

Tabel 5. Distribusi responden berdasarkan IMD dan ASI Eksklusif

\begin{tabular}{|c|c|c|c|c|c|c|c|}
\hline \multirow{3}{*}{ Karakteristik } & \multicolumn{6}{|c|}{ Praktik Pemberian ASI } & \multirow{3}{*}{$\begin{array}{l}\text { Hasil uji chi- } \\
\text { square } \\
\text { (P value) }\end{array}$} \\
\hline & \multicolumn{2}{|c|}{ Non Eksklusif } & \multicolumn{2}{|c|}{ Eksklusif } & \multicolumn{2}{|c|}{ Total } & \\
\hline & $\mathrm{n}$ & $\%$ & $\mathbf{N}$ & $\%$ & $\mathbf{n}$ & $\%$ & \\
\hline \multicolumn{8}{|l|}{ Inisiasi Menyusu Dini (IMD) } \\
\hline Tidak melakukan IMD & 19 & 59,4 & 13 & 40,6 & 32 & 100 & 0,025 \\
\hline Melakukan IMD & 8 & 27,6 & 21 & 72,4 & 29 & 100 & \\
\hline
\end{tabular}

Tingkat pengetahuan responden paling baik adalah tentang manfaat ASI dengan jumlah responden menjawab benar sebanyak $100 \%$, sedangkan paling rendah tentang daya tahan bayi baru lahir tanpa makanan atau minuman dengan jumlah responden menjawab dengan benar $41,0 \%$. Pola menyusui didapatkan hasil bahwa pola menyusui secara Eksklusif (55,7\%). Namun masih terdapat pola menyusui parsial sebesar $36,1 \%$ dan menyusui predominan sebesar $8,2 \%$. Sebanyak 13 bayi $(48,1 \%)$ pada penelitian ini telah mendapatkan makanan prelakteal. Alasan diberikan makanan prelakteal karena ASI belum keluar, bayi rewell dan takut bayi kelaparan. Berdasarkan jenisnya didapatkan hasil $84,6 \%$ berupa susu formula. Alasan ibu memilih susu formula sebagai makanan prelakteal yaitu karena susu formula dianggap sebagai pengganti ASI, praktis dan mudah didapat.

Pencapaian Asi Eksklusif dalam penelitian ini mencapai 55,7\%. Angka tersebut masih di bawah pencapaian pemberian ASI Eksklusif di tingkat Puskesmas pada tahun 2015 Yaitu 71,65\% dan belum mencapai Target nasional yaitu cakupan ASI Eksklusif 0-6 bulan sebesar $80 \%^{2}$. Sosialisasi mengenai ASI Eksklusif di Puskesmas Ayah I dilakukan melalui berbagai kegiatan seperti pada saat kegiatan Kelas Ibu Hamil, Program Perencanaan dan Pencegahan Komplikasi (P4K) dan juga kegiatan Penyuluhan mengenai ASI Eksklusif. Kegiatan kelas Ibu hamil dilakukan 1-2 kali dalam setahun pada tiaptiap desa menyesuaikan ketersediaan anggaran dari pemerintah, sedangkan untuk kegiatan penyuluhan dengan materi ASI Eksklusif tidak terdapat jadwal pasti, karena materi penyuluhan berbeda-beda setiap bulannya.

\section{Hubungan pengetahuan, IMD, dan ASI eksklusif}

Variabel yang dianalisis yaitu pengetahuan ibu, praktik IMD dan praktik pemberian ASI Eksklusif. Hasil penelitian didapatkan hasil bahwa tingkat pengetahuan sebesar $41,0 \%$ termasuk kategori baik. Analisis chi-squre antara pengetahuan ibu dengan ASI eksklusif didapatkan hasil $p=0,000(p<0,05)$, artinya terdapat hubungan antara dua variabel tersebut. Pengetahuan akan mempengaruhi perilaku seseorang dalam mengambil sikap. Tingkat pengetahuan dikelompokkan menjadi 6 tingkat yaitu mulai dari tahu, paham, aplikasi, analisis, sintesis dan terakhir yaitu evaluasi ${ }^{18}$. Hal ini sejalan dengan beberapa penelitian lain yang juga menyebutkan bahwa terdapat hubungan antara pengetahuan ibu dengan pemberian ASI eksklusif ${ }^{29,30,31}$.

Bayi dari manusia sebenarnya serupa dengan bayi mamalia lainnya yang mampu melakukan kegiatan menyusu secara mandiri. Dengan membiarkan kontak kulit secara langsung antara ibu dan bayi kurang lebih selama satu jam segera setelah bayi lahir, bayi 
akan merangkak untuk mencari payudara. Kegiatan ini mampu meningkatkan kepercayaan ibu untuk memberikan ASI kepada bayinya ${ }^{23}$. Keterkaitan antar variabel IMD dengan ASI eksklusif di puskesmas Ayah I dilakukan dengan uji chi-squre dan didapatkan hasil $p=0,025 \quad(p, 0,05)$. Artinya terdapat hubungan antara dua variabel tersebut. Hal ini sejalan dengan penelitian (Fikawati \& Syafiq (2009) bahwa 5 dari 7 informan yang melaukan IMD berlanjut memberikan ASI secara eksklusif ${ }^{14}$. Dengan melakukan inisiasi menyusu dini, ibu akan semakin percaya diri untuk terus memberikan ASI secara eksklusif dan bayi akan merasa nyaman saat terjadi kontak kulit dengan ibu ${ }^{32}$.

\section{KESIMPULAN}

Kesimpulan yang diperoleh yaitu terdapat hubungan antara pengetahuan ibu dan IMD dengan pemberian ASI secara eksklsif di Puskesmas Ayah I. Berdasarkan hal tersebut maka dapat disarankan bagi ibu menyusui, hendaknya lebih banyak lagi menggali informasi terkait ASI eksklusif dan bagi petugas kesehatan, disarankan untuk memberikan informasi kepada masyarakat sejak dini agar mempunyai waktu yang lebih banyak dalam melakukan persiapan dan perencanaan dalam menyusui. Kegiatan ini bisa dilakukan kepada calon pengantin ketika akan melakukan imunisasi TT di puskesmas. Kekurangan dari penelitian ini yaitu hanya meneliti variabel pengetahuan dan IMD saja, padahal masih banyak variabel lain yang mempengaruhi keberhasilan ASI eksklusif.

\section{ACKNOWLEDGEMENT}

Penulis mengucapkan terima kasih kepada Dosen Departemen Gizi Kesehatan FKM UNAIR yang telah membimbing dan mengajar selama ini.

\section{REFERENSI}

1. WHO. Infant and young child feeding. World Health Organization 2011;155(May):p.A3929. Tersedia di: <http://whqlibdoc.who.int/publications/2 009/9789241597494_eng.pdf>.

2. Kemkes RI. Situasi $d n$ anaalisis ASI eksklusif. Pusat data dan informasi kemetrian kesehatan republik Indonesia. 2014. Terdapat di : http://www.depkes.go.id/resources/down load/pusdatin/infodatin/infodatin-asi.pdf.

3. Badan Pusat Statistik. Survei Demografi dan Kesehatan Indonesia tahun 2012. Sdki. 2013. Terdapat di: http://www.depkes.go.id/resources/down load/pusdatin/profil-kesehatanindonesia/profil-kesehatan-indonesia2012.pdf.

4. Badan penelitian dan pengembangan kesehatan. RISKESDAS (Riset Kesehatan Dasar) Tahun 2013, Jakarta. 2013. Terdapat di http://www.depkes.go.id.resources/down load/general/Hasil Riskesdas 2013.pdf.

5. Dinkes Jateng. Profil tentang Kesehatan Provinsi Jawa Tengah 2013. 2013. Terdapat di : http://www.depkes.go.id/resources/down load/profi/PROFIL_KES_PROVINSI_2013/1 3_prov_Jateng_2013.pdf.

6. Dinkes Jateng. Profil tentang Kesehatan Provinsi Jawa Tengah 2014. 2014. Terdapat di http://www.depkes.go.id/resources/down load/profil/PROFIL_KES_PROVINSI_2014/1 3_Jateng_2014.pdf.

7. Dinkes Jateng. Profil tentang Kesehatan Provinsi Jawa Tengah 2015. 2015. Terdapat di : http://www.depkes.go.id/resources/down load/profil/PROFIL_KES_PROVINSI_2015/1 3_Jateng_2015.pdf.

8. Dinkes Kebumen. Profil Kesehatan Kabupaten Kebumen 2013, Kebumen. 2014.

9. Dinkes Kebumen. Profil Kesehatan Kabupaten Kebumen 2014, Kebumen. 2015.

10. Dinkes Kebumen. Profil Kesehatan Kabupaten Kebumen 2015, Kebumen. 2016.

11. Depkes RI. Juknis SPM Penyelenggaraan Perbaikan Gizi Masyarakat. Depkes RI Ditjen Bina Kesehtan Masyarakat Direktorat Gizi Masyarakat. Jakarta. 2004. 
Tersedia di : http://gizi.depkes.go.id/wpcontent/uploads/2012/05/SPM_Gizi.pdf.

12. Fikawati S, Syafiq A, Karima K. Gizi ibu dan bayi.Jakarta : Raja Grafindo Persada. 2015.

13. Kemenkes RI. Materi Penyuluhan Inisiasi Menyusu Dini, Jakarta: Dirjen Bina Gizi dan KIA. 2014.

14. Fikawati S, Syafiq A. Penyebab kegagalan dan keberhasilan pemberian ASI Eksklusif. kesmas : National public health journal 2009;4(3):120-131. terdapat di:http://download.portalgaruda.org/artic le.php?article $=269769 \&$ val $=7113 \&$ title $=$ pe nyebab keberhassilan dan kegagalan praktik pemmberian ASI eksklusif.

15. Hasanah IP, Nindya TS. Kontribusi IMD dan Dukungann Suami pada riwayat ASI eksklusif bayi usia 6-12 bulan. Media Gizi Indonesia 2015;10(1):44-50.

16. Badan Penelitian dan pengembangan Kesehatan. RISKESDAS (Riset Kesehatan Dasar) Tahun 2010. Jakarta. 2010. Tersedia di

http://www.kemkes.go.id/development/si te/depkes/pdf.php?id=1-16031300001.

17. Rizkianti A, Novianti. Pemberian Asupan Prelakteal sebagai saalah satu faktor kegagalan ASI eksklusif pada pekerja buruh tekstil Jurnal Kesehatan Reproduksi 2013;5(1):23-26. terdapat di : http://ejournal.litbang.depkes.go.id/index .php/kespro/article/view/3880.

18. Notoatmojo S. Promosi kesehatan dan perilaku kesehatan. Jakarta : Rineka Cipta. 2012.

19. Legesse $M$, Demena $M$, Mesfin F, Haile, Demewoz. Prelacteal feeding practices and associatied factors among mothers of children aged less than 24 months in Raya Kobo district, Nort Eastern Ethiopia : a cross-sectional study. Internasional breastfeeding journal 2014;9(I):189. terdapat di

http://internationalbreastfeedingjournals. biomedcentral.com/articles/10.1186/s130 06-014-0025-2.

20. Rohmin A, Malahayati N, Hartati. Faktor yang mempengaruhi praktik pemberian makanan prelaktal pada bayi baru lahir di bukit kecil palembang. Kesehatan 2015;6:183-189. terdapaat di : http://ejournal.poltekkes-

tjk.ac.id/index.php/JK/article/view/104.

21. Puskesmas Ayah I. Profil Kesehatan Puskesmas Ayah I 2013, Kebumen. 2014.

22. Puskesmas Ayah I. Profil Kesehatan Puskesmas Ayah I 2014, Kebumen. 2015.

23. Puskesmas Ayah I. Profil Kesehatan Puskesmas Ayah I 2015, Kebumen. 2016.

24. Nursalam. Metodologi penelitian dalam ilmu keperawatan. Edisi 4. Jakarta : Salemba Medika. 2016.

25. Utami R. Inisiasi Menyusu DIni dan ASI eksklusif. Jakarta. Pustaka Bunda. 2008.

26. Arini H. Mengapa ibu harus menyusui. Cetakaan I. Yogyakarta : Flash Books. 2012.

27. Rahmawati $A$, Bahar $B$, Salam $A$. Hubungan antara karakteristik ibu,peran petugas kesehatan dan dukungan keluarga dengan pemberian ASI eksklusif di puskesmas Bonto Cani Bone Makassar. Program studi ilmu gizi fakultas kesehatan maasyarakat UNHAS. 2012. pp 1-16.

28. Dahlan A, Mubin F, Mustika DN. hubungan ststus pekerjaan dengan pemberian ASI eksklusif di palebon, pedurungan Semarang. Jurnal Unimus 2011;1-5. terdapat di

http://jurnal.unimus.ac.id/index.php/jur_ bid/article/viewfile/1021/1069.

29. Mariane W, Laoh JM, Pangemanan DH. Hubungan pengetahuan, sikap dengan pemberian ASI eksklusif pada busui puskesmas bahu manado. ejurnal keperawatan 2013;1-7. terdapat di : http://e-

journal.unsrat.ac.id/index.php/article/do wnload/2199/1757.

30. Aprilia G. Hubungan tingkat pengetahuan ibu dengan pemberian ASI Eksklusif di Harjobinangun Purworejo. ejournal.akbid.purworejo 2012;55. terdapat di : http://ejournal.akbid.purworejo.ac.id/index.php/j kk5/article/view/73.

31. Lestari D, Zuraida R, Larasati T. Hub. tingkat pengetahuan ASI, pekerjaan ibu dengan pemberian ASI eksklusif di kelurahan fajar bulan. Medical journal of lampung university 2013;88-99. terdapat di : juke. kedokteran.unila.ac.id/ indexph/ majority / articles/ view/66. 
32. Fikawati S, Syafiq A. Kajian implementasi dan kebijakan ASI eksklsif dan IMD di Indonesia. Makara 2010;14(1):17-24. terdapat http://journal.ui.ac.id/index.phhp/health/ articles/view/642/627. 